\begin{tabular}{|l|l|l}
\hline & $\begin{array}{l}\text { Proceedings of the } \\
\text { Informing Science }+\end{array}$ & $\begin{array}{l}\text { An Official Publication } \\
\text { of the Informing Science Institute } \\
\text { InformingScience.org }\end{array}$ \\
\hline
\end{tabular}

June 30 - July 4 2019, Jerusalem, Israel

\title{
ETHOS, PATHOS AND LOgOS: RHETORICAL FIXES FOR AN OLd PROBLEM: FAKE NEWS
}
A. J. Grant
Robert Morris University, Moon, granta@,rmu.edu PA, USA.

\begin{abstract}
Aim/Purpose

The proliferation of fake news through social media threatens to undercut the possibility of ascertaining facts and truth. This paper explores the use of ancient rhetorical tools to identify fake news generally and to see through the misinformation juggernaut of President Donald Trump.

Background The ancient rhetorical appeals described in Aristotle's Rhetoric - ethos (character of the speaker), pathos (nature of the audience) and logos (message itself)—might be a simple, yet profound fix for the era of fake news. Also known as the rhetorical triangle and used as an aid for effective public speaking by the ancient Greeks, the three appeals can also be utilized for analyzing the main components of discourse.

Methodology Discourse analysis utilizes insights from rhetoric, linguistics, philosophy and anthropology in in order to interpret written and spoken texts.

Contribution This paper analyzes Donald Trump's effective use of Twitter and campaign rallies to create and sustain fake news.

Findings At the point of the writing of this paper, the Washington Post Trump Fact Checker has identified over 10,000 untruths uttered by the president in his first two years of office, for an average of eight untruths per day. In addition, analysis demonstrates that Trump leans heavily on ethos and pathos, almost to the exclusion of logos in his tweets and campaign rallies, making spectacular claims, which seem calculated to arouse emotions and move his base to action. Further, Trump relies heavily on epideictic rhetoric (praising and blaming), excluding forensic (legal) and deliberative rhetoric, which the ancients used for sustained arguments about the past or deliberations about the future of the state. In short, the analysis uncovers how and ostensibly why Trump creates and sustains fake news while claiming that other traditional news outlets, except for FOX news, are the actual purveyors of fake news.
\end{abstract}

Accepted by Executive Review by Editor Eli Cohen | Received: October 6, 2018 | Revised: October 23, November 2, November 7, 2018 | Accepted: November 8, 2018.

Cite as: Grant, A. J. (2019). Ethos, pathos and logos: Rhetorical fixes for an old problem: Fake news. Proceedings of the Informing Science and Information Technology Education Conference, Jerusalem, Israel, pp. 81-91. Santa Rosa, CA: Informing Science Institute. https://doi.org/10.28945/4154

(CC BY-NC 4.0) This article is licensed it to you under a Creative Commons Attribution-NonCommercial 4.0 International License. When you copy and redistribute this paper in full or in part, you need to provide proper attribution to it to ensure that others can later locate this work (and to ensure that others do not accuse you of plagiarism). You may (and we encourage you to) adapt, remix, transform, and build upon the material for any non-commercial purposes. This license does not permit you to use this material for commercial purposes. 
Ethos, Pathos and Logos

Recommendations Information systems and communication practitioners need to be aware of the for Practitioners ways in which the systems they create and monitor are vulnerable to targeted attacks of the purveyors of fake news.

Recommendation Further research on the identification and proliferation of fake news from a variefor Researchers ty of disciplines is needed, in order to stem the flow of misinformation and untruths through social media.

Impact on Society The impact of fake news is largely unknown and needs to be better understood, especially during election cycles. Some researchers believe that social media constitute a fifth estate in the United States, challenging the authority of the three branches of government and the traditional press.

Future Research As noted above, further research on the identification and proliferation of fake news from a variety of disciplines is needed, in order to stem the flow of misinformation and untruths through social media.

Keywords fake news, facts, misinformation, disinformation, alternative facts

\section{INTRODUCTION}

Fake News has been with us since people organized themselves into tribes with power differentials among its members (Burkhardt, 2017), but the technological innovations of the printing press, newspapers, then radio and television made possible widespread circulation of fake news. The internet sped up this process and allowed for the creation of fake news websites, which provided "entertainment, satire and parody," but also "misinformation and misdirection," which clearly had "more serious and sinister motives" (Burkhardt, 2017, p. 22). It is the rise of social media, especially Facebook, Twitter and Instagram, which have allowed for the global sharing of and commenting on fake news instantaneously. This paper uses Tornero, Tyle, Tejedor, and Pulido's definitions for the following key terms: "A fact is checked and contrasted, it offers indications of its integrity and can be consulted or checked by anybody. In contrast fake news is information that imitates an informative style of news but gives false information." Further, "an alternative fact is an interpretation of reality, but in no case can be considered a fact." Finally, "fake news is that which contains false information and is disseminated mainly by social networks ... [even though] they have also been evidenced in newspapers and other media in recent times" (Tornero et al., 2018, p. 228, my italics).

Tornero et al. (2018) argue for the creation of a new field—news literacy — to address the constellation of forces and institutions that have come together to shape the "era of fake news" (Albright, 2017, p. 87). This new field would ostensibly incorporate insights from linguistics, semiotics, pragmatics, sociology, social psychology, political science, media studies, AI, robotics, and data science (Tornero et al., 2018). Sounds complicated. How could one even begin to incorporate insights from these variegated fields into a set of proactive analytical tools? In this paper I suggest that the ancient rhetorical appeals described in Aristotle's Rhetoricethos (character of the speaker), pathos (nature of the audience) and logos (message itself)—might be a simple, yet profound fix for the era of fake news. Also known as the rhetorical triangle and used as an aid for effective public speaking by the ancient Greeks, the three appeals can also be utilized for analyzing the main components of discourse.

When we ask questions about the ethos of a message we are asking who crafted the message and to what end, moving into the realms of rhetoric, anthropology, psychology, and social psychology. When we ask questions about the logos of the message we move into the realms of linguistics, semiotics, rhetoric, and pragmatics (and especially what is now being called multimodal discourse). The pathos of a message has to do with the audience, and more specifically which emotions might be engaged in this audience in order to effectively move it to action, which moves us into the realm of audience psychology, mass media studies, and political science. The glue of this triangle for Aristotle was human speech, but we can readily update the medium to digital, social networks, which have largely displaced the spoken word, moving us into the realms of mass media studies, AI, information science, and even robotics.

This paper will use an updated version of the rhetorical triangle, informed by a number of the disciplines identified above, to analyze President Donald Trump's speeches, use of Twitter, and campaign rally speeches to create and sustain fake news. At the point of the writing of this paper, the Washington Post Trump Fact 
Checker has identified over 5000 untruths uttered by the president in his first two years of office, for an average of eight untruths per day (Kessler, 2018, passim). In addition, analysis demonstrates that Trump leans heavily on ethos and pathos, almost to the exclusion of logos in his tweets and campaign rallies, making spectacular claims, which seem calculated to arouse emotions and move his base to action. Further, Trump relies heavily on epideictic rhetoric (praising and blaming), excluding forensic (legal) and deliberative rhetoric, which the ancients used for sustained arguments about the past or deliberations about the future of the state. In short, the analysis uncovers how and ostensibly why Trump creates and sustains fake news while claiming that other traditional news outlets, except for FOX news, are the actual purveyors of fake news.

\section{A QUESTION OF IMBALANCE}

Wayne Booth (1963) argued that all good writing (and speaking) ought to include the thoughtful use of the "rhetorical triangle"-ethos, pathos, and logos - where ethos represents the "voice" or style of the writer or speaker as well as the character; pathos, the audience's perceptions, needs, feelings, age and education; and logos, the actual content of the written or spoken message. This "rhetorical triangle" has been one of the mainstays of rhetorical education in the West for the last 2300 years, but is often ignored by news outlets' sensationalist and biased reporting. What Booth argues is that effective communicators avoid overemphasis on a single appeal, anchoring the presentation in all three appeals (ethos, pathos, and logos), rather than in one or two.

To drive the point home, Booth (1963) identifies three common imbalances: too much appeal to me, myself, and my style (ethos), Booth refers to as the "Entertainer's Stance," which he defines as "the willingness to sacrifice substance to personality and charm" (p. 144). Too much appeal to the content (logos) and one has the stance of the "Pedant," which consists of "ignoring or underplaying the personal relationship of speaker and audience and depending entirely on statements about a subject--that is, the notion of a job to be done for a particular audience is left out" (p. 141). If one appeals too much to the audience (pathos), this constitutes the "Advertiser's Stance," which comes from "undervaluing the subject and overvaluing pure effect: how to win friends and influence people" (p. 143). President Trump, the self-proclaimed dealmaker, gravitates toward over reliance on ethos and pathos.

\section{THE ENTERTAINER: DONALD TRUMP'S ETHOS}

President Trump's The Apprentice first appeared in 2004 and had a fifteen series run. Contestants vied for a place in one of Trump's companies and were subjected to brutal interviews, most of which ended with the now famous, "You're fired!" Originally a builder, Trump branched out into entertainment and the proliferation of Trump products, including cologne and clothing lines. The rhetoric of his political speeches, from the Inaugural address through his first address to the United Nations is a self-absorbed rhetoric, featuring himself and his exploits in an often entertaining manner. The same is true of his tweets, all of which are updated daily, archived, and categorized (Trump Twitter Archive, 2018). An analysis of Trump's major speeches and his tweets shows that he relies heavily on ethos, boasting about his character, his wealth, and his accomplishments: unabashedly promoting the Trump Brand.

Given this over reliance on ethos, Trump exhibits a fondness for epideictic rhetoric, which includes the subtopics of virtue/vice and praising/blaming. His speeches are largely devoid of forensic rhetoric (substantive arguments based on the past and used in the law courts) and deliberative rhetoric (arguments for future political actions), which ask the two fundamental questions of whether or not a course of action is worthy of the United States and/or advantageous to the nation. This consistent use of epideictic rhetoric reduces Trump's speeches and tweets to self-absorbed adulation and the praise of his friends with a concomitant condemnation of his enemies. In addition, this narrowing of the president's rhetoric is a radical departure from contemporary presidential rhetoric, including that of Barak Obama, George W Bush, Bill Clinton, and others.

The Republican Convention Speech (Trump, 2016) easily divides into the twin and opposite categories of Virtue/Praise and Vice/Blame, the stuff of epideictic rhetoric with a strong admixture of ethos. On the virtue side of this black and white divide stands Trump, Sarah Root (murdered by an illegal alien), three sets of parents (children murdered by illegals), and the "American People." On the vice side of the divide stands "political correctness," illegal immigrants, "murdering immigrants," President Obama, Hillary Clinton and the "elites" who dominate the media and politics. After Trump "humbly and gratefully" accepts the nomination from the party, he claims that together they will "lead our country back to safety, prosperity, and peace." But the tone changes quickly as he paints a post-apocalyptic landscape for the present: "attacks" on police, "ter- 
Ethos, Pathos and Logos

rorism," "danger" in the cities, and "violence" and "chaos" everywhere. Then he launches into a series of "I" statements, which run throughout the speech: "I have a message for all of you: the crime and violence that today afflicts our nation will soon come to an end. Beginning on January $20^{\text {th }} 2017$, safety will be restored" (para. 3).

The remainder of the speech is a first person narration of how Trump will take on the legacy of the democrats and Hillary Clinton—a legacy of "death, destruction and weakness" (Trump, 2016, para 5), with the rather astonishing claim that "I alone can fix it" (para 11). The "I" statements in this speech read rather like the ego eimi (I am) statements in the gospel of John where Jesus claims, "I am the good shepherd, the true vine, the way the life and the truth," etc. Perhaps this is no accident. Trump says, "I am your voice," I have no patience for injustice," "I am not able to look the other way," "I alone can fix it," "I will restore law and order," I have a different vision," I have made billions of dollars," "I am going to make our country rich again." The speech ends with Trump giving the audience his pledge of identification with the downtrodden: "I'm with you - the American People," and, finally, "I'm with you, and I will fight for you, and I will win for you" (para 48). In fairness to Trump, the speech actually ends with the first person plural: "We will make America Proud again. We will make America safe again. And we will make America Great again." But, given the number of self-references in the speech, it seems most likely that these plurals are instances of the royal "we": Trump, himself and he. In addition to this speech displaying the Entertainer imbalance described by Booth (1963), this is quintessential Fake News. First, the U.S. is not overrun with murdering immigrants, nor is there danger, chaos and violence everywhere, so there really is nothing to fix. Second, even if the post-apocalyptic picture painted by Trump is accurate, Trump alone cannot fix it. No president has that kind of power.

Trump's Inaugural Address (Trump, 2017) again sets up a clear, black and white divide between Virtue and Vice, good and evil, but the first person plural pronoun "we" predominates. "We" are Trump and the "American people," "the people," "factories," and "citizens." The Vice side of the binary includes "DC," "Washington," "politicians," and "the establishment." After the requisite acknowledgements, Trump sets up the Vice/Virtue binary, which carries the speech forward:

Washington flourished-but the people did not share its wealth.

Politicians prospered—-but the jobs left and the factories closed.

The establishment protected itself, but not the citizens of our country.

Today, according to Trump, all of this changes, because on this day, 20 January, "the people became the rulers of this nation again" and they came "by the tens of millions to become part of a historic movement the likes of which the world has never seen before" (my italics). This is his claim, but again, no arguments are developed. What we have is a long string of disconnected, unsubstantiated claims following the black and white divide set up at the beginning of the speech. We are witnessing some kind of messianic phenomenon, because in the midst of the chaos and the "carnage" - "now arrives the hour of action." In addition to wiping out radical Islamic terrorism, bringing jobs and factories back, and making America safe, prosperous, and great again, "We stand at the birth of a new millennium, ready to unlock the mysteries of space, to free the Earth from the miseries of disease, and to harness the energies, industries and technologies of tomorrow." And he ends with a flourish:

Together we will make America strong again.

We will make America wealthy again.

We will make America proud again.

We will make America safe again.

And, yes, together, we will make America great again. Thank you. God bless you, and God bless America.

This is deeply religious, apocalyptic language, replete with a reference to the "millennium," the 1000 year reign of Christ on earth. Christian Pre-millenialists would get the message, and some would busy themselves with trying to figure out how Trump fits into the End Times playbook. Christian Post-millenialists could read this as a clear message that the 1000 year reign of Christians had arrived, at the end of which Christ returns. Amillenialists wouldn't care, because the millennium in Revelation is viewed as a metaphor. It is impossible to 
know with certainty how these groups heard this inaugural address of President Trump, but clearly, something extraordinary, something with eschatological and cosmic significance is at hand.

But the place to really capture the entertainment ethos of this president as well as his penchant for creating fake news, is on his Twitter feed, since it discourages the development of sound arguments and allows for short, unsubstantiated claims about himself, and he thinks very much of himself as the following tweets illustrate:

1. "My I.Q. is one of the highest - and you all know it!"

2. "I will be the best by far in fighting terror"

3. "I will be the greatest job-producing president in American history"

4. "I am the BEST builder, just look at what I've built"

5. "I am the best builder but if that were my building with the crane mishap..."

6. "I am attracting the biggest crowds, by far, and the best poll numbers, also by far."

7. "I am least racist person there is"

8. "I am in Las Vegas, at the best hotel (by far), Trump International"

9. "I am at Trump National Doral-best resort in U.S."

10. "Donald Trump's Palm Beach mansion...which I turned into the greatest club in the world"

11. "Many people have commented that my fragrance, "Success" is the best scent \& lasts the longest"

12. "Many people have said I'm the world's greatest writer of 140 character sentences."

13. "Many are saying I'm the best 140 character writer in the world" (Trump Twitter Archive, 2018)

Further, Trump's claim in his Inaugural Address that he alone can fix the world's problems is confirmed in earlier and later tweets:

1. "Nobody but Donald Trump will save Israel"

2. "Nobody knows jobs like I do!"

3. "Nobody understands politicians like I do"

4. "Nobody beats me on National Security"

5. "Nobody would fight harder for free speech than me"

6. "Nobody can beat me on the economy (and jobs)"

7. "Nobody will protect our Nation like Donald J. Trump"

8. "Nobody more against Obamacare than me"

9. "Nobody has more respect for women than Donald Trump!"

10. "No-one has done more for people with disabilities than me"

11. Illegal immigration "Our Southern border is unsecure. I am the only one that can fix it"

12. Infrastructure "all falling apart. I can fix for $20 \%$ of pols, \& better"

13. ISIS "ISIS is still running around wild. I can fix it fast"

14. Jobs "I am the only presidential candidate who will bring jobs back to the U.S. and protect car industry!"

15. Social Security "I am going to save Social Security without any cuts. I know where to get the money from. Nobody else does."

16. Tax laws "I know our complex tax laws better than anyone who has ever run for president and am the only one who can fix them."

17. Making America great "I am the only one who can Make America Great Again" (Trump Twitter Archive, 2018)

And to round out his Entertainment ethos, Trump has thirteen tweets singling out the highest rated TV shows and events-ever--Face the Nation, SNL, Meet the Press, WrestleMania 23-which featured, yes, you guessed it, Trump himself. In short, Trump's speeches and many of his tweets feature himself as the only one who can fix the world's problems, divide the world into those who are with him and those against him, and vilify and castigate those who report "Fake News" about him.

\section{FAKE NEWS: DONALD TRUMP'S LOGOS}

So what is the content of Trump's communications? We pretty much covered the content above: whatever is wrong in the nation and the world he and he alone will and can fix. This is serious fake news, but it does end with claims about himself. According to Glenn Kessler (2018), creator of the Washington Post's "Fact Check- 
Ethos, Pathos and Logos

er: The Truth Behind the Rhetoric,' 'Trump has spoken or written over 5000 misleading or false statements over the last three years, averaging eight "lies" per day. This makes Trump a virtual fountainhead for fake news, the very thing he so often accuses the major news outlets of creating. And, attacking the Press is one of Trump's favorite Twitter activities. As of the writing of this paper (16 October 2018) Trump used the phrase "Fake News" 287 times in his Twitter feed, with the first use on 10 December 2016. His last ten tweets about fake news I list below:

1. Oct 16, 2018 08:15:18 AM - For the record, I have no financial interests in Saudi Arabia (or Russia, for that matter). Any suggestion that I have is just more FAKE NEWS (of which there is plenty)!

2. Oct 10, 2018 08:01:05 AM - Despite so many positive events and victories, Media Reseach Center reports that $92 \%$ of stories on Donald Trump are negative on ABC, CBS and ABC. It is FAKE NEWS! Don't worry, the Failing New York Times didn't even put the Brett Kavanaugh victory on the Front Page yesterday-A17!

3. Oct 6, 2018 04:57:09 PM - The crowd in front of the U.S. Supreme Court is tiny, looks like about 200 people (\& most are onlookers) - that wouldn't even fill the first couple of rows of our Kansas Rally, or any of our Rallies for that matter! The Fake News Media tries to make it look sooo big, \& it's not!

4. Sep 16, 2018 04:40:19 PM - Watch@MariaBartiromo at 6:00 P.M. on @FoxBusiness. Rus-sian Hoax the big topic! Mainstream Media, often referred to as the Fake News Media, hates to discuss the real facts!

5. Sep 14, 2018 10:08:11 PM - When President Obama said that he has been to "57 States," very little mention in Fake NewsMedia. Can you imagine if I said that...story of the year! @IngrahamAngle

6. Sep 13, 2018 07:28:12 PM - RT @LouDobbs: \#FakeNews- the Hurricane Maria death tolls have been inflated \& President @realDonaldTrump was right to call out organiza-tion...

7. Sep 6, 2018 06:19:30 AM - The Deep State and the Left, and their vehicle, the Fake News Media, are going Crazy - \& they don't know what to do. The Economy is booming like never before, Jobs are at Historic Highs, soon TWO Supreme Court Justices \& maybe Declassification to find Additional Corruption. Wow!

8. Sep 4, 2018 09:58:21 AM - NBC FAKE NEWS, which is under intense scrutiny over their killing the Harvey Weinstein story, is now fumbling around making excuses for their probably highly unethical conduct. I have long criticized NBC and their journalistic standards-worse than even CNN. Look at their license?

9. Sep 2, 2018 09:10:17 AM - RT @realDonaldTrump: .@Rasmussen_Poll just came out at 48\% approval rate despite the constant and intense Fake News. Higher than Election D...

10. Aug 31, 2018 09:25:38 PM - .@Rasmussen_Poll just came out at 48\% approval rate de-spite the constant and intense Fake News. Higher than Election Day and higher than President Obama. Rasmussen was one of the most accurate Election Day polls! (Trump Twitter Archive, 2018)

Let's check the facts.

1. In 2006 Trump actually said that he earns millions, perhaps hundreds of millions from sales of Trump products to Saudi Arabia.

2. The Media Research Center, which provided the $92 \%$ statistic is a conservative research company, which largely ignores the positive things said about Trump by CNN, MSNBC and other more "liberal" news outlets.

3. The crowd in front of the Supreme Court was much larger than 200 people-- 168 people alone were arrested.

4. FOX News does present the Russia investigation by Mueller as a hoax, but there have been numerous indictments and it looks like Michael Cohen is getting ready to flip.

5. Obama did slip and refer to having been to 57 states in May 2008, and he was vilified for it by elements of the Press. 
6. The Hurricane Maria death toll was not inflated-it rose because people were dying of post hurricane causes.

7. Trump is boasting about the economy booming and his supreme court nominations and he identifies the Left with the so-called Deep State, which if it exists at all, would be connected largely to conservative causes.

8. It is true that NBC may have tried to shut down Ronan Farrow's investigation of Harvey Weinstein's sexploits, but there has been a shake-up at NBC, including the firing of Matt Lauer for sexual harassment. Still, does this make their journalistic standards "worse even than CNN"? The "Look at their license?" quip is a threat and an argument ad bacculum, a logical fallacy regularly employed by Trump.

9. (9 and 10.) Trump's approval ratings across all the polls for the last two years have hovered between 38\% and 40\% as opposed to Clinton's, Bush II's and Obama's, which hovered around $50 \%$ for the better part of their presidencies.

So, an analysis of Trump's most recent Tweets about fake news demonstrates that though there are elements of truth in some of the tweets (57 States, 92\% negative stories, NBC killing Weinstein story, etc.) the other tweets contain misleading or flat-out false information. Again, If "fake news is information that imitates an informative style of news but gives false information ... and is disseminated mainly by social networks ..." (Tornero et al., 2018, p. 228, my italics), then Trump's tweets, which constitute the lion's share of his presidential (mis)communication are excellent examples of the very phenomenon he vilifies and condemns.

Finally, Trump likes to bash political opponents and, for example, has vilified President Obama in 64 tweets, who is also listed with 42 people and institutions who are "the worst." Obama also tops a list of 18 people who "don't have a clue (Including Elizabeth Warren, David Brooks, Mitt Romney, Karl Rove, Jeb Bush, to name a few.). And, as of today, there are 298 tweets castigating news reporters and outlets, including Cookie [sic] Roberts ("so wrong for so long"), Anthony Baxter ("bias and stupidity ... clowns"), Arianna Huffington ("ugly both inside and out"), Bill Kristol ("dopey . . lost all credibility with so many dumb statements"), Brian Williams ("not a very smart guy"), Bryan Gumbel ("one of the dumbest racists around ... an arrogant dope with no talent"), Charles Krauthammer ("pretends to be a smart guy ... dummy ... an overrated clown"), and the list goes on and on and on. I include a sample of these tweets below:

1. Chris Matthews "he gets dumber each \& every year--\& started from a very low base" $(04 / 16 / 2013)$

2. Chris Matthews "lowest IQ on television" (04/16/2013)

3. Chuck Todd "sleepy eyes...an absolute joke of a reporter" (10/08/2012)

4. Chuck Todd "sleepy eyes...one of the dumbest voices in politics" (08/09/2013)

5. Chuck Todd "sleepy eyes...ratings on Meet the Press are setting record lows..he's a real loser" $(01 / 25 / 2015)$

6. CNBC "ratings are really low, worst in many years" (08/29/2013)

7. CNN's Ana Navarro "no talent, no TV persona" (11/09/2015)

8. CNN's Don Lemon "lightweight - dumb as a rock" (08/10/2016)

9. CNN's Errol Louis "doesn't have a clue" (11/30/2015)

10. David Axelrod "the dog hit me even after I made a big contribution to his charity" (02/10/2015)

11. David Gregory "thrown off of TV by NBC, fired like a dog...being nasty to me...not nice" $(03 / 30 / 2016)$

12. David Letterman "so boring and mundane...world-shattering poor performance at the Academy Awards a number of years ago" (02/22/2012)

13. Erick Erickson "major sleaze and buffoon" (08/08/2015) (Trump Twitter Archive, 2018)

Today (16 October 2018), the president referred to Stormy Daniels as "horse-face" after she lost her defamation lawsuit against him and also referred to Elizabeth Warren as "Pocahontas" when she tested positive for Native American ancestry. All the tweets above exhibit the logical fallacy of the argument ad hominem, argument against the person, which includes name-calling, the lowest form of this fallacy and an important component of the fake news, false information disseminated by Trump through Twitter. Far from exhibiting Booth's (1963) imbalance of the Pedant-too much reliance on content alone--Trump's communications are almost content free in terms of solid claims and arguments about the nation or the world, but filled with ad 
Ethos, Pathos and Logos

bacculum (threats) and ad bominen (insults and name-calling) fallacies as well as a preponderance of fake newsmisinformation and falsehoods mixed in with a few verifiable facts.

\section{SELLING THE TRUMP BRAND: DONALD TRUMP's PATHOS}

On November 8, 2016, Donald Trump was elected president of the United States, much to the surprise of the whole nation, including Republicans, Democrats, pollsters, media talking heads, and even Trump himself. "The election of a race-baiting, misogynist alleged billionaire with no political experience forced many analysts to re-think their assumptions about secular morality and political persuasion. It also forced a collective re-evaluation of who the 'ordinary citizen' was — or at least the ordinary citizen who had no problem voting for a reality TV star who was not only an outsider but who seemed to have no interest in anything that anyone previously thought constituted normal politics" (Berezin, 2017, p. 322). Somehow, Trump managed to convince enough ordinary citizens that he too was an ordinary citizen and would be their voice in Washington. After Trump won the Nevada Primary he thanked his supporters, "I love the poorly educated!" and then added, "We are the smart people, we are the most loyal people" (Berezin, 2017, p. 324). The poorly educated, smart people, it turns out, live all over the United States and they bought his message (Berezin, 2017, p. 324). And this is Trump's ethos as well as his pathos, his strong appeal to his base. Born in Queens, not Manhattan, Trump did go to Penn and he did receive a sizeable loan from his father to set him up in business, but he also convinced his base that he was a tough kid from Queens who built buildings, rubbing shoulders not with the elite, but with architects, contractors, and bricklayers.

And his language was crude, vulgar, and simple. The more religious people ignored the crudity and vulgarity, but they understood the simple vocabulary, short sentences and colorful stories. "The consensus view seems to be that Trump appeals to large sections of the American electorate because his language is closer to the plain, simple and direct speech of "ordinary" people ... than it is to the notoriously rarified, convoluted and evasive language typically associated with mainstream political rhetoric" ("Editorial," 2017). Trump consistently uses personal pronouns - especially I and we-to create a sense of identification with his base and is notorious for using repetition to reinforce his message as in the double use of "God bless America" in his Inaugural Address. Trump's primary audience is his loyal political base- the 38\%-40\% who have supported him for the last three years, enduring the lies and scandals and cheering him on at his second favorite communication medium - campaign rallies, which are currently in full swing as the midterm elections approach. His tweets about his supporters are pure flattery:

Jun 16, 2018 08:12:14 AM - My supporters are the smartest, strongest, most hard working and most loyal that we have seen in our countries history. It is a beautiful thing to watch as we win elections and gather support from all over the country. As we get stronger, so does our country. Best numbers ever! [Twitter for iPhone]

Oct 8, 2016 02:40:48 PM - The media and establishment want me out of the race so badly - I WILL NEVER DROP OUT OF THE RACE, WILL NEVER LET MY SUPPORT-ERS DOWN! \#MAGA [Twitter for Android]

Sep 27, 2016 09:17:06 PM - My supporters are the best! \$18 million from hard-working people who KNOW what we can be again! Shatter the record: https://t.co/8ZHGyOth0f [Twitter for iPhone]

Sep 10, 2016 01:18:37 PM - While Hillary said horrible things about my supporters, and while many of her supporters will never vote for me, I still respect them all! [Twitter for Android]

Sep 10, 2016 07:47:18 AM - Wow, Hillary Clinton was SO INSULTING to my supporters, millions of amazing, hardworking people. I think it will cost her at the Polls! [Twitter for Android]

Jun 3, 2016 02:07:26 PM - Great evening in San Jose other than the thugs. My supporters are far tougher if they want to be, but fortunately they are not hostile. [Twitter for iPhone]

Mar 20, 2016 01:52:32 PM - The protesters blocked a major highway yesterday, delaying entry to my RALLY in Arizona by hours, and the media blames my supporters! [Twitter for Android]

Mar 13, 2016 06:48:44 AM - Bernie Sanders is lying when he says his disruptors aren't told to go to my events. Be careful Bernie, or my supporters will go to yours! [Twitter for Android] 
Jan 11, 2016 10:40:48 AM - Just arrived in New Hampshire. Thank you to all of my supporters! \#MakeAmericaGreatAgain \#Trump2016 https://t.co/KSgulhkIwa [Twitter for iPhone]

Oct 18, 2015 05:50:10 PM - Best thing my supporters can do if you don't like the way @megynkelly and her puppets unfairly treat "us" is don't watch her show! [Twitter for Android] (Trump Twitter Archive, 2018)

Berezin (2017) argues that Trump's constant talk about building buildings and doing business had a strong appeal to working class people and that between June 2015 and election day 2016 Trump brought this message of hard work and its rewards to millions of supporters at hundreds of campaign rallies. "Trump's speeches follow a familiar, repetitive script... Analysts overlooked the praise of physicality and materiality that imbue Trump's speeches. Building and doing, the physicality, as well as the denigration of mental laborare constitutive of virtually all his speeches (Berezin, 2017, p. 326).

Trump's call to the working class and the professional classes of makers and doers seems to have dovetailed perfectly with the growing popularity of Ayn Rand's fiction and prose described by Gary Weiss' Ayn Rand Nation: The bidden struggle for America's soul (2012). Both Atlas Shrugged and The Fountainhead had been popular with Newt Gingrich and the early Tea Party members as well as with Alan Greenspan, former Chairman of the Fed, who was a good friend and disciple of Rand's, and, more recently, with Paul Ryan, current Speaker of the House of Representatives. Trump is a perfect incarnation of Howard Roark, the besieged and visionary architect of Fountainhead, who is persecuted by leftist politicians and labor unions as he dreams and builds his glorious skyscrapers. But he is also Dagney Taggart of Atlas Shrugged, a brilliant and beautiful railroad tycoon and capitalist who is also hassled by organized undesirables and almost prevented from realizing her dream of building the fastest train in the world. In 2011, 445,000 copies of the English edition of Atlas Shrugged were sold or distributed by the Ayn Rand Institute and a total of 1.5 million copies had been sold since Obama was elected president, according to Dr. Yaron Brook, executive director of the Ayn Rand Institute ("Atlas Shrugged Still Flying off the Shelves," 2012).

Trump's entertainment ethos and ethic reflects perfectly Ayn Rand's Virtue of selfishness: A new concept of egoism published in 1964. Rand articulated a version of ethical egoism in the book, the view that everyone ought to look out for oneself and oneself exclusively, effectively undercutting normative claims for altruism. This is a very different position than psychological egoism, which argues that humans are inherently selfish. Selfishness is elevated to a virtue, unthinkable in the Western philosophical canon, beginning with Socrates, who, in all his conversations with his disciples warned that if they did not care for their own souls, they could not care for others, but care of others, altruism, is still a charge from the old philosopher. His final words to Phaedo and Crito? "Take care of yourselves, nothing new, what I have always said" (Plato, 360 B.C.E./1990, p. 393).

For Rand, selfishness is merely "concern with one's self-interest" and that interest in and care for the other, altruism, has created a brute:

The ethics of altruism has created the image of the brute, as its answer, in order to make men [sic] accept two inhuman tenets: (a) that any concern with one's own interests is evil, regardless of what these interests might be, and (b) that the brute's activities are in fact to one's own interest (which altruism enjoins man [sic] to renounce for the sake of his neighbors). (p. 5)

This, of course, is a caricature of altruism that neither Socrates nor Aristotle would have recognized. Even Jesus' call to love ones neighbor as oneself is predicated on a fundamental love of oneself. Rand instructs her readers to consult her works of fiction, especially Atlas Shrugged to get a fleshed out picture of what she means by selfishness. What we find in figures like Taggart and Roark are self-absorbed capitalists who build and do and amass incredible wealth in the process. They don't marry or have children, because they don't have time for such pedestrian affairs, but they do have steamy affairs with other wealthy people committed to building and doing. When asked what his favorite books were shortly after being elected, Trump named three- two of his own and The Fountainhead. Rand's novel of the embattled architect appealed to Trump, because, in Trump's own words, "It relates to business (and) beauty (and) life and inner emotions. That book relates to ... everything" (Ha, 2017, para 2). 
Ethos, Pathos and Logos

\section{CONCLUSION: DONALD TRUMP AS ENTERTAINER, ADVERTISER AND PURVEYOR OF FAKE NEWS}

An analysis of Trump's major speeches and his tweets shows that he relies heavily on ethos, boasting about his character, his wealth, and his accomplishments, an imbalance described by Booth (1963) as the Entertainer's Stance. Trump also relies heavily on pathos, advertising the Trump Brand ad nauseum to his base, which sees a reflection in Trump of Ayn Rand's fictional protagonists who build and do. Trump's logos is empty of solid claims and arguments about issues and problems confronting the nation and the world, but filled with ad bacculum (threats) and ad bominen (insults and name-calling) fallacies as well as a preponderance of fake newsmisinformation and falsehoods mixed in with a few verifiable facts. The imbalance in Trump's rhetoric, identified by using the rhetorical triangle to analyze his speeches and tweets, is fixable, if only he would allow his speech writers to develop more solid communication content or permit editing of his tweets and campaign rally speeches by his staff. Booth's audience for the "Rhetorical Stance" was first year college composition teachers.

But even if the rhetorical triangle is heeded and Trump restores some kind of balance to his communication, the Bully Pulpit of the U.S. presidency has been turned into a pulpit of the bully who sees only himself and his adoring supporters. It is an ongoing reality TV show featuring Donald Trump selling himself and his brand to his faithful consumers. This is a deeper problem about a narcissistic entertainer and promoter of the Trump Brand turned president.

As for the proliferation of fake news by this president--this also cannot be easily fixed. Courses in news literacy, suggested by Tornero et al. (2018) will certainly help, and Kessler's Fact Checker at The Washington Post, which is bi-partisan is encouraging, as is the daily fact checking at the major news outlets. But it is doubtful that Trump himself will change, as so many former White House staffers have learned only too painfully. The midterms are approaching at the writing of this paper and Trump is on the stump with his overall approval ratings rising in all the polls.

\section{REFERENCES}

Albright, J. (2017). Welcome to the era of fake news. Media and Communication, 5(2), 87-89. https://doi.org/10.17645/mac.v5i2.977

Atlas Shrugged still flying off the shelves. (2012) Ayn Rand Institute. Retrieved from https://ari.aynrand.org/mediacenter/press-releases/2012/02/14/atlas-shrugged-still-flying-off-shelves

Berezin, M. (2017). On the construction sites of history: Where did Donald Trump come from? American Journal of Cultural Sociology, 5(3), 322-337. https://doi.org/10.1057/s41290-017-0045-7

Booth, W. (1963). The rhetorical stance. College Composition and Communication, 14(3), 139-145. https://doi.org/10.2307/355048

Burkhardt, J. (2017). Combating fake news in the digital age. Library Technology Reports, 53(8).

Editorial. (2017). English Today, 130(33), 1. https://doi.org/10.1017/S0266078417000165

Ha, T. H. (2017). All the books Donald Trump said he's read and liked. Quart\%. Retrieved from https://qz.com/852495/the-art-of-the-deal-all-the-books-donald-trump-has-publicly-said-hes-read-and-liked/

Kessler, G. (2018). Fact checker. The Washington Post. Retrieved from https://www.washingtonpost.com/news/factchecker/wp/2015/11/?utm term=.f951b4557e6a

Plato. (1990). The Phaedo. Plato I: (H. North Fowler, trans.). Loeb classical library. Cambridge: Harvard UP. (Original work published in 360 B.C.E.)

Rand, A. (1964). Virtue of selfishness: A new concept of egoism. New York: Penguin (Signet).

Tornero, J., Tayle, S., Tejedor, S., \& Pulido, C. (2018). How to confront fake news through news literacy? State of the art. Doxa.comunicacion, 26, 211-235.

Trump, D. (2016) Donald Trump 2016 RNC draft speech transcript. Politico. Retrieved from https://www.politico.com/story/2016/07/ full-transcript-donald-trump-nomination-acceptance-speech-at-rnc225974 
Trump, D. (2017). The Inaugural Address. https://www.whitehouse.gov/briefings-statements/the-inaugural-address/

Trump Twitter Archive. (2018). Available at http://trumptwitterarchive.com/

Weiss, G. (2012). Ayn Rand Nation: The bidden struggle for America's soul. St. Martins: New York.

\section{BIOGRAPHY}



A. J. Grant is a University Professor of Organizational Leadership at Robert Morris University in Pittsburgh, PA. Grant's research interests include historical and contemporary topics in rhetoric, ethics, the humanities and leadership. Grant has recently published articles on the humanities and leadership and leadership education. 